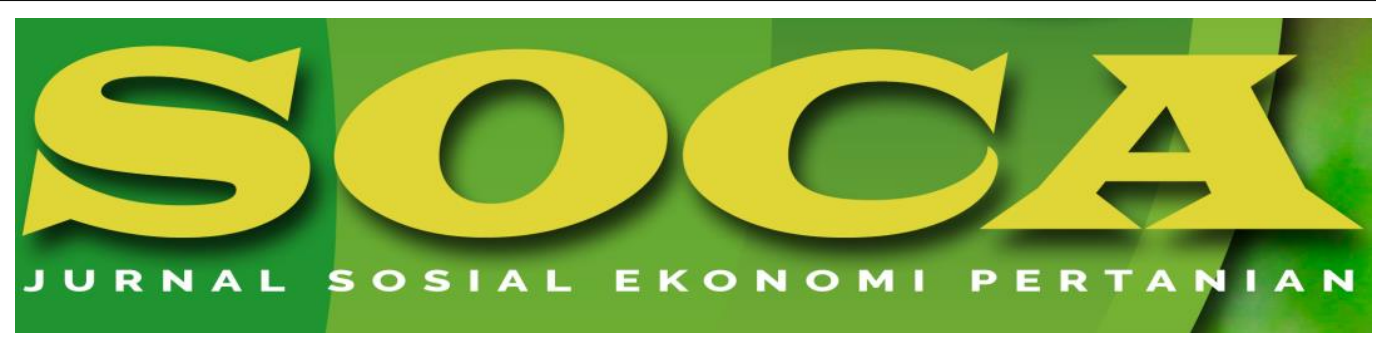

https://ojs.unud.ac.id/index.php/soca

\title{
The Benefits and Problems in the Implementation of the Special Effort of Rice, Corn, Soybean Production Enhancement Program
}

\author{
Valeriana Darwis, Chairul Muslim and Yonas Hangga Saputra \\ Indonesian Center for Agricultural Socio and Economic Studies (ICASEP), Bogor, West Java \\ Province \\ Email:valicfurca@gmail.com, chairulmuslimc@gmail.com and yogtra@gmail.com \\ Mobile: 081380552136,081314241761 and 085221307567
}

Submitted: March 19th 2020 ; Revised : April 9th 2020 ; Accepted: May 24th 2020

\begin{tabular}{l}
\hline Keywords: \\
Technology; \\
Benefits; \\
Problems; \\
Program \\
\hline
\end{tabular}

\begin{abstract}
The Special Efforts of Rice, Corn and Soybean Production Enhancement Program has been performed since 2015 and in its implementation several benefits and problems have been identified. The aim of this research was to identify the benefits, problems as well as the adoption and feedback of the application of technological innovation in East Java Province. The survey was conducted in June 2019 with data and information analysis conducted descriptively with the discussion utilized the deepening results through focus group discussion. The deepening results showed the benefits of participating in the program, which were: increased institutional activity, increased knowledge, and increased productivity. On the other hand, the problems were: the recipient was not in accordance with $C P C L /$ prospective farmers and location; seed aid was not enough, it was not as expected and it was too late; Agricultural machine tools aid was still less and the size did not match the cultivated land. The expected feedbacks from technological innovation side were: (i) seed varieties aid adjusted to the location and farmers expectation also the arrival has to be on time and right amount; (ii) agricultural machine tools aid was not only for rice, the type and size of the agricultural machine tools followed the conditions of farmers' land and training for the operators who operate it.
\end{abstract}


How to Cite (APA 6th Style):

Darwis, V., Muslim, C., \& Saputra, Y. H. (2020). The Benefits and Problems in the Implementation of the Special Effort of Rice, Corn, Soybean Production Enhancement Program. SOCA: Jurnal Sosial Ekonomi Pertanian, 14(3), 412423. https://doi.org/https://doi.org/10.24843/SOCA.2020.v14.i03.p03

\section{INTRODUCTION}

The Special Efforts of Rice, Corn and Soybean Production Enhancement Program (abbreviated as Upsus Pajale), performed based on the Minister of Agriculture Regulation No. 03/Permentan/OT.140/2/2015. The Upsus Pajale Program was created to resolve the problems of: (i) limited land, (ii) water quality and irrigation systems, (iii) agricultural labor was increasingly rare, labor fee were high, and there was a lack of agricultural mechanization equipment, (iv) the provision of production facilities has not achieve six proper principle and (v) farmers' access to financial institutions. The Upsus Pajale Program has been performed since 2015 with the focus on government efforts in increasing rice, corn, soybeans, beef, sugar cane, chilli, and onion production.

The implementation of Upsus program, especially in rice, corn and soybean, was at least able to develop farming business patterns through machine tools aid and rice production infrastructure ai; increased IP/agricultural index and production, and improved farming business efficiency (Hamayana. 2017). Some of the benefits felt by farmers participants in East Tanjung Jabung Regency included: (i) an increase in rice field area has a significant effect in rice production enhancement by $5.25 \%$, (ii) an increase in seed subsidy by $6 \%$ caused an increase in rice productivity to $30.51 \%$, (iii) an increase in fertilizer subsidy by $6 \%$ will increase productivity by $0.34 \%$ and (iv) an increase in agricultural machine tools aid by $6 \%$ will increase productivity by $10.71 \%$ (Busyra. 2016). The same thing was also disclosed by Wijaya (2016) where rice productivity after the Upsus Pajale program in Subak Gadungan Delod Village, Gadungan Village, Tabanan Regency became 5.44 tons / hectare. The increase in rice productivity after the Upsus Pajale program was 0.93 tons / hectare or exceeded the government's increased productivity target $(0.3$ tons / hectare).

On the other hand, problems that arised in the implementation of Upsus Pajale Program in South Lampung Regency were: (i) poor quality seed aid, (ii) late availability of fertilizer, (iii) communication between counselors and farmer groups was rarely and has never been performed and ( iv) difficulties in borrowing agricultural equipment given by the government to the head of the farmer group (Anisa 2018). Communication problems in implementation were also raised by Nurlaili et al (2019) which seen in Tulungagung Regency, where the counselors with Babinsa/village police officer and counselors with mantri tani/farming paramedics were not yet effective in conveying messages, because each prioritized the interests of each institutions. The problem of the poor quality of seeds aid and agricultural machinery aid that was not yet efficient was also raised by Nugroho et al (2017) in Wonosobo Regency.

Technological innovation in the Upsus Pajale program was one of the main requirements in increasing rice, corn and soybean production. The intended technological innovations were: the use of varieties; mechanization of land 
management, planting equipment, maintenance, harvesting and post-harvesting; and institutions that support cultivation activities. But in its implementation, the application of technological innovation in one program may not be in accordance with the program implementation location. Therefore the aim of this research was: (i) identify the implementation of Upsus Pajale in East Java Province, (ii) identify the benefits and problems of the implementation of the Upsus Pajale program, and (iii) identify the adoption and feedback of the technology innovation application of Upsus Pajale program.

\section{RESEARCH METHODS}

The Upsus Pajale Program began in 2015 and was performed simultaneously in several provinces in Indonesia, which were in Central Java, East Java, North Sumatra, South Sulawesi, Jambi, West Kalimantan, South Kalimantan and Central Kalimantan. This research was conducted in 2019 in East Java Province. The selection of the research locations was done purposively based on: (i) the provinces that implementing the Upsus Pajale program and (ii) the provinces with the highest rice production and harvested area. Based on BPS/Central Bureau of Statistics data in 2018, East Java had the highest contribution of rice production and harvested area to the national rice production and harvested area, compared to other provinces that received Upsus Pajale programs as well. The contribution of rice production and harvested area of East Java Province were each 15.7\% and 37.6\%. Furthermore, the selection of districts used the same method by considering the suggestion from BPTP East Java.

The chosen locations were Malang Regency, Sidoarjo Regency and Lamongan Regency. Site survey conducted in June with secondary and primary data collection activities. Secondary data was obtained from the Department of Agriculture of the Regency and East Java BPTP, while the primary data was obtained in sequences starting from: (i) discussed about program implementation in the East Java BPTP office; (ii) conducted FGD at the Regency Official office with presented participants were representatives of the Department of Agriculture of the Regency, East Java BPTP, counselors, assistants, farmer groups, UPJA/Agriculture Equipment Service management and farmers; and (iii) visited the location where the activity was performed.

The collected data was then analyzed descriptively by discussing the benefits, problems, adoption and feedback of the application of technological innovation of the Upsus Pajale program. Descriptive method was a method used to describe or analyze a research result but was not used to make broader conclusions (Sugiyono. 2005).

\section{RESULTS AND DISCUSSION Upsus Pajale Program}

There were two strategies used in the implementation of Upsus Pajale activities, which were: (1) basic strategies that were focused on: (i) increasing productivity and cropping index through increase the availability of irrigation water, seeds, fertilizers, and Agricultural machine tools; (ii) providing mentoring facilities from agricultural counselors, researchers, universities and the Indonesian National Army (TNI); (iii) irrigation development activities, land optimization, rice corn soybean GP-PTT/Integrated Planting Technology Movement, soybean PAT-PIP/Plant Intensity 
Enhancement and Planting Area Expansion programs, and corn PAT; (iv) rice land optimization was not given seed aid. (2) Operational strategies were needed to ensure the effectiveness of the implementation of sustainable self-sufficiency achievement in rice, corn and soybeans.

The operational hierarchy included the tasks allocation that starts from the central, provincial, regency / city and sub-district levels. While the mentoring involved stakeholders in the Ministry of Agriculture, Agency, Counselors, Bintara/Police Officer, Village Coach, Universities, as well as from the TNI. The mentors had an active role as communicators, facilitators, advisors, motivators, educators, organizers and dynamists in order to implement special efforts activities to increase rice, corn and soybean production in achieving self-sufficiency and sustainable self-sufficiency in food commodities (Wahyudi, 2015).

The assistant role of student was important because it was the link between the University' which has various technological innovations with farmers. Irmayanda et al (2016) revealed that farmers' perceptions of assistants (Students and Alumni) had a good role in the Upsus Pajale Program. In the Upsus Pajale assistance activities in Nagan Raya Regency, $82 \%$ of farmers stated that the assistants' role of Upsus Pajale in Nagan Raya Regency was good and $18 \%$ of respondents indicated that it was not good. The assistants' duty of counselors, students and babinsa can be seen in Table 1.

Table 1. Mentors and Assistants' Duty of Counselors, Students and Babinsa

\begin{tabular}{|c|c|c|c|}
\hline No. & Counsellors & Students & Babinsa \\
\hline 1 & $\begin{array}{l}\text { Implemented } \\
\text { mentoring and } \\
\text { assisting in GPPTT } \\
\text { implementation; } \\
\text { accelerated in land } \\
\text { optimization; } \\
\text { rehabilitated tertiary } \\
\text { irrigation system } \\
\text { (RJIT); planting area } \\
\text { addition (PAT) and } \\
\text { demfarm/farming } \\
\text { demonstration }\end{array}$ & $\begin{array}{l}\text { Together with the } \\
\text { counsellors implemented } \\
\text { mentoring and assisting in } \\
\text { performing GPPTT, POL, } \\
\text { RJIT, PAT and demfarm }\end{array}$ & $\begin{array}{l}\text { Encouraged and motivated } \\
\text { the farmers to perform } \\
\text { simultaneously planting; } \\
\text { improvement } \\
\text { maintenance irrigation } \\
\text { system } \\
\text {; OPT and harvest control } \\
\text { movement }\end{array}$ \\
\hline 2 & $\begin{array}{l}\text { Improved institutional } \\
\text { farmers' ability } \\
\text { (Poktan, Gapoktan, } \\
\text { P3A and GP3A) and } \\
\text { economic farmers' } \\
\text { ability. }\end{array}$ & $\begin{array}{l}\text { Together with the } \\
\text { counsellors facilitated } \\
\text { technology introduction in } \\
\text { increasing rice, corn and } \\
\text { soybean production which } \\
\text { produced by University } \\
\text { through demfarm; } \\
\text { developed farmers' model } \\
\text { empowerment }\end{array}$ & $\begin{array}{l}\text { Performed support in } \\
\text { certain circumstance for } \\
\text { seed distribution, fertilizers } \\
\text { and Agriculture machine } \\
\text { tools; irrigation system } \\
\text { infrastructure }\end{array}$ \\
\hline 3 & $\begin{array}{l}\text { Developed networks } \\
\text { and partnerships with } \\
\text { businessmen. }\end{array}$ & $\begin{array}{l}\text { Together with the } \\
\text { counsellors developed } \\
\text { networks and partnerships } \\
\text { with businessmen }\end{array}$ & $\begin{array}{l}\text { Performed a control to the } \\
\text { administration filing and aid } \\
\text { distribution to the receivers }\end{array}$ \\
\hline 4 & $\begin{array}{l}\text { Performed } \\
\text { identification, }\end{array}$ & $\begin{array}{lr}\text { Together } & \text { with the } \\
\text { counsellors } & \text { performed }\end{array}$ & $\begin{array}{l}\text { Performed a control to the } \\
\text { identification, data }\end{array}$ \\
\hline
\end{tabular}


collection and identification, data collection and technical technical report of the collection and technical report of the implementation implementation report of the implementation activities. activities. activities.

Source: The Ministry of Agriculture 2015

\section{Implementation of Upsus Pajale Program in East Java}

BPTP of East Java as the person in charge in Supervision and Assistance of Upsus self-sufficiency Pajale Program in 7 Regencies (Bangkalan, Gresik, Mojokerto, Pamekasan, Sampang, Sidoarjo and Sumenep). With the activities as of: 1) IP enhancement through accelerating irrigation system improvement, repairing reservoirs and pumping, 2) area expansion and land optimization, 3) agricultural machine tools aid to reduce labor scarcity especially in planting, cultivation and harvesting (reducing yield loss), 4) escort and mentoring of farmers in the adoption of technology by researchers, counsellors, TNI, lecturers, students and other stakeholders, and 6) cooperated with other Ministries and SOE.

Some of the activities were performed by East Java BTPT in the 2018 fiscal year including:

(i) Acceleration of addition planting area with realization of 2,250,605 $\mathrm{Ha}$ (Table 2),

Table 2. Realization of Addition Rice Planting Area in East Java Province

\begin{tabular}{ccccc}
\hline \multirow{2}{*}{ No } & Province & \multicolumn{2}{c}{ Realization LTT (Ha) } & \multirow{2}{*}{\begin{tabular}{c} 
OCT-MAR \\
\cline { 3 - 4 }
\end{tabular}} \\
\cline { 3 - 4 } & $\mathbf{2 0 1 7 / 2 0 1 8}$ & APR-SEP 2018 & \\
\hline 1 & Jember & 95.265 & 66.990 & 162.255 \\
2 & Bojonegoro & 122.363 & 37.223 & 159.586 \\
3 & Lamongan & 100.355 & 49.222 & 149.577 \\
4 & Ngawi & 92.787 & 44.804 & 137.591 \\
5 & Banyuwangi & 66.516 & 58.297 & 124.813 \\
6 & Pasuruan & 68.154 & 49.849 & 118.003 \\
7 & Tuban & 69.968 & 37.668 & 107.636 \\
8 & Malang & 40.505 & 28.100 & 68.605 \\
9 & Sidoarjo & 14.305 & 11.954 & 26.259 \\
10 & Others & 803.100 & 393.181 & 1.196 .280 \\
\hline & TOTAL & 1.473 .318 & 777.288 & 2.250 .605 \\
\hline
\end{tabular}

Source: BPTP of East Java. 2019

(ii) Seeds and publication aid which were in one activity series in increasing effort of rice productivity. To introduce Pajale Balitbangtan seed which has high yield potency, BPTP of East Java had distributed seeds aid (Table 3) Stimulants distribution in the form of seeds aid was also aimed to make farmers were willing to do planting acceleration. Besides rice and corn seeds aid, it also had been delivered to the farmers and administration officers and leaflet about specific technology of Pajale cultivation location. 
Table 3. Seeds Aid and Print Dissemination Media in East Java Province

\begin{tabular}{ccc}
\hline NO & Aid Variety & Quantity \\
\hline 1. & Inpari 33 Rice Seed & $370 \mathrm{Kg}$ \\
2. & Inpari 32 Rice Seed & $2.300 \mathrm{Kg}$ \\
3. & Inpari 43 Rice Seed & $500 \mathrm{Kg}$ \\
4. & Situbagendit Rice Seed & $1.000 \mathrm{Kg}$ \\
5. & Corn Seed & $90 \mathrm{Kg}$ \\
6. & Superior Variety Book 2010-2016 & 500 books \\
7. & Technical Guidance Book of Tumpangsari & 1000 books \\
& Pajale & 1.000 sheets \\
8. & Leaflet of Tumpangsari Corn and Soybean & 1.000 sheets \\
9. & Leaflet of Tumpangsari Rice and Corn & 1.000 sheets \\
10. & Leaflet of Tumpangsari Rice and Soybean & \\
\hline
\end{tabular}

Source: East Java BPTP. 2019

(iii) Monoculture demonstration plots were performed in order to provide concrete examples in the ground about good cultivation techniques. With the demonstration plot method, farmers can see and implement the steps of technology implementation to increase productivity from the beginning to harvesting. Demonstration plots had been performed in Jombang, Pamekasan, Banyuwangi, Gresik, Jombang and Bangkalan Regency (Table 4). The technology applied in the rice demonstration plot was "Jarwo Super" technology. This technology combined PTT with utilized the biodecomposers, biological fertilizers and Agriculture machine tools utilization. The demonstration plot in Jombang was an effort to resolve the land with poor drainage due to inappropriate chemical fertilization treatment. The technologies applied included deep cultivation using a 4-wheeled tractor, using organic fertilizer and decomposers, using $\mathrm{ZnSO} 4$, and replacing the $\mathrm{N}$ source with Za fertilizer.

Table 4. Demonstration Plot of Increasing Productivity in East Java Province

\begin{tabular}{cccccc}
\hline No & Regency & Commodity & $\begin{array}{c}\text { Planting } \\
\text { Start }\end{array}$ & $\begin{array}{c}\text { Previous } \\
\text { Productivity }\end{array}$ & $\begin{array}{c}\text { Productivity } \\
\text { After } \\
\text { Demonstration }\end{array}$ \\
\hline 1 & Jombang & RICE & $\begin{array}{c}\text { December } \\
2017\end{array}$ & 5 ton/ha & 9 ton $/$ ha \\
2 & Banyuwangi & RICE & April 2018 & 5,32 ton/ha & 8,13 ton $/ \mathrm{ha}$ \\
3 & Gresik & RICE & April 2018 & 8,8 ton $/ \mathrm{ha}$ & 10,5 ton $/ \mathrm{ha}$ \\
4 & Jombang & RICE & March 2018 & 5 ton $/ \mathrm{ha}$ & 7 ton $/ \mathrm{ha}$ \\
5 & Banyuwangi & RICE & August 2018 & 4 ton/ha & 8,5 ton $/ \mathrm{ha}$ \\
\hline
\end{tabular}

Source: East Java BPTP. 2019

(iv) Tumpang Sari/multiple cropping Demonstration Plot. One of the Ministry of Agriculture's breakthroughs in order to increase LTT as well as to increase land productivity was by applying multiple cropping patterns (Table 5). Multiple cropping' system which implemented was multiple cropping gogo rice-corn, gogo rice-soybean and corn-soybean. Multiple cropping applied in this activity was a dense cropping system so that it was expected from one hectare of land can be recorded in BPS, the two commodities that planted. In order to guard the Pajale multiple cropping development activity, East Java BPTP has held Pajale multiple 
cropping demonstration plots in 7 Regencies. Accompaniment was performed on an area of 1 to 2 hectares in locations that got multiple cropping activities from APBN funding.

Table 5. Demontration Plot Location of Pajale Multiple Cropping in East Java Province

\begin{tabular}{cllc}
\hline No & Regency & Multiple Cropping & Area (Ha) \\
\hline 1. & Situbondo & Rice-Corn & 1 \\
2. & Probolinggo & Rice-Corn & 1 \\
3. & Malang & Rice-Corn Rice- & 2 \\
4. & Sampang & Soybean & 1 \\
5. & Tuban & Corn-Soybean & 2 \\
6. & Pamekasan & Rice-Corn & 1 \\
7. & Nganjuk & Rice-Corn & 1 \\
\hline
\end{tabular}

Source: EastJava BPTP. 2019

\section{The Benefits and Problems of UPSUS PAJALE Program Implementation}

There were several positive impacts felt by farmers who participated in the Upsus Pajale program, which were:

i. Farmer Group Institutions.

Although there were no additions in the number of farmer group members, but from the side of activity there were additional activities that made the group meetings more intensive; specifically, in discussing planting time and how to maintain and treat the plants properly.

ii. Seed Breeder.

With the existence of Upsus program that introduced superior seeds made by the Ministry of Agriculture's Research and Development to farmer members, resulted the demand for superior seeds was increasing. With this opportunity, there were some farmers who try to become breeders and for breeders, who previously did not work on superior seed varieties, were now starting to work on superior seeds. The superior seeds that were much sought by farmers were Inpari 30, 32 and 42 varieties

iii. Farming Stall.

There was no increase in farming stall in the program location, but there were farming stall which before not sell now have already sold superior rice seeds of Inpari 30, 32 and 42 varieties.

iv. Increased Production.

An increase in production of farmers who participated in the program was between 500-1000 kg per ha. This increase was improved in farmers who previously planted Ciherang rice varieties into Inpari varieties. The Ciherang production was between 6-7 tons GKP (grain)/ ha, while Inpari 32 production can reach 7-8 tons GKP (grain)/ ha.

v. Quality Improvement.

Improved quality of rice yields caused by farmer members had begun to use mechanization in their cultivation. Farmers will get clean, full grain when using a combine machine at harvest time. With clean and solid grain, the selling price 
has increased by an average of Rp. 300 per kg when compared to manual grain yields.

vi. Job vacancy.

Although not many, there were opportunities for new jobs and recruitment of new workers. This happens because skilled workers who can run the agricultural equipment aid needed. In addition, professional and creative workers have emerged in repairing agricultural equipment if it was damaged or modifying agricultural equipment so that it can be used (specific location).

vii. Land Optimization.

Although not much and because of limited land, the farmers who participated in the Upsus program planted corn on their yards.

viii. Adding Knowledge.

This was the result of the obligation of farmers who participated in the program have to attend the technical guidance (Bimtek). The addition of knowledge especially in the cultivation technology advice; types and superior varieties and post-harvest processes were using agricultural tools.

Instead, the problems that appeared in the implementation of the Upsus Pajale program including:

i. CPCL Movement.

The placement of the program has not been planned carefully. This caused during the implementation of the aid, there was a CPCL movement and one of the causes was land incompatibility.

ii. Seed

Rice seeds received by farmers were only $25 \mathrm{~kg}$ per hectare and this was still far from the amount of seeds normally used by farmers for about 40 to $50 \mathrm{~kg}$ per hectare. The varieties of soybean seeds received by the farmers were dislike, because they produced small soybean grain, while traders prefer larger soybean grain. There were still corn seeds that come after planting time. As a result, farmers did not plant or continued to plant but their productivity was not optimal. Because it was an aid, the varieties that farmers received were sometimes inappropriate or not commonly planted by farmers.

iii. Tractor.

The availability of tractors was still less, this was felt during the simultaneous planting season. This condition caused farmers to experience a delay in planting between 3 to 4 days.

iv. Transplanter.

Planting machines aid or transplanter that was given was not in accordance with the conditions of the land. On a narrow area the size of the transplanter aid was large and vice versa on a small area the large size machine was given. Farmers got use to planting by using labors, so that they did not need a planting machine.

v. Planting Technique.

Not all farmers used the jarwo planting system and if there was anyone using the jarwo system but the space measure were different between regions

vi. Maintenance.

Not all farmers used maintenance technology as recommended. This was because the level of human resources in Bimtek was very diverse and the stock 
availability in buying inputs was not the same between each other. Recommended organic fertilizer was Petroganik, was not used by farmers because farmers prefer to use organic fertilizer from animal waste (kohe).

vii. Combine

The same condition happened with the transplanter machine which was not following the land topography. As a result, the agricultural machine aid was not used to maximum.

viii. Irrigation.

This problem was especially felt by farmers who participated in the program that were far from water sources.

\section{The Adoption and Feedback on the Implementation of the Rice Upsus Technology Innovation Program}

Rice seed varieties given were varieties that have been determined by the Ministry of Agriculture. The varieties of rice were Inpari 30, Inpari 32 and Inpari 42. In the beginning of the program some farmers did not want to use government' determined varieties seeds. But along the time and farmers saw an increase in yield, then eventually the farmers willing to plant these varieties. But the problem was that at the simultaneous planting time and farmers agreed to use the same variety, the Inpari variety seeds were not available in sufficient amount.

Seed aid received by each farmer in one hectare was $25 \mathrm{~kg}$. Meanwhile farmers were used to plant 40 to $50 \mathrm{~kg}$ in one hectare. So the for the deficiency, farmers used different varieties. This condition can cause unequal growth and was expected to cause a decrease in production.

Agricultural machine tools aid consisted of: land cultivation equipment, planting machine and harvesting equipment. But in practice the three types of machines were not all obtained by one group. There were also groups that got agricultural tools but cannot maximize their application. This was because the land of the farmer group member was quite large and not enough to be processed by just one aid machine.

There were obtainable agricultural machine tools that were not suitable to the land conditions. The rice fields were wide but the aid received was agricultural equipment that has a small capacity. The same thing happened on narrow land but the aid of agricultural equipment was large agricultural tools / machines. In addition, the aid should also give a concern to the condition of the land. For wet land, it was not suitable to use large size combines. This was due to the tool will not be able to run because of sinking, especially during the rainy season. Transplanters were suitable for land that has easy organized irrigation. Otherwise, land with manual irrigation was mostly used on irrigated land that cannot be controlled. The transplanter was suitable in the area of South Lamongan Regency which was easy to adjust the water level. On the other hand, in northern Lamongan, transplanters were difficult to implement because of the high water levels that were difficult to adjust.

The planting technology recommended in the program was the jajar legowo (jarwo) planting system 2: 1 . But in the implementation, not all farmers used it. There were also farmers who used jarwo with a larger size. There were also farmers using the planting direct seeds system (abbreviated as tabela) by using site-specific 
machine engineering. In fact there were still farmer members who use planting teams (custom planting labors) in the cultivation of rice farming business.

Major irrigation improvements had not yet been made and were still limited in maintenance. The water management still used pre-existing patterns. The problem that arisen was actually not on the water drain, but on the source of water which was inadequate, especially in farmers who were far from the irrigation water drain or the land was located above the irrigation drain. To overcome this, farmers usually used water pumps. But things that cannot be overcome by farmers, was how to adjust the flow of irrigation water so it was not to flood during the rainy season and dry during the dry season.

\section{Corn Upsus}

Corn seed varieties included in the aid package were Bisi 2 and Bima varieties. Bima variety was a variety produced by the Ministry of Research and Development, but in Bima variety production was much less than Bisi productivity. One of the reasons was because the Bima corncobs were not fully filled especially in the corn tip. The difference in productivity can reach 2 tons per hectare. Therefore, in the cultivation there were still many farmers who used Bisi 2 and Bisi 19 corn varieties. There was still corn seeds aid that came after the planting season. But in terms of needs, the amount of corn seeds received was the same as the seed planted, which was $15 \mathrm{~kg}$.

There was no specific technology for cultivation and farmers were used to cultivating it for generations. For dry land, the cultivation process used a tractor and vice versa corn that planted in rice fields did not need to be process, but directly planted. Dry land was sometimes too hard and cannot be processed using a tractor. According to farmers, land processing machines that suitable for hard land were using cultivator machines.

Corn planting tool that used was a planting tool engineered by farmers themselves. The tool was made from motorcycle alloy wheels in facilitating movement and was connected to the paralon pipe as a planting tool. This creativity arose because the planting system commonly used by farmers was a tugal system by using bamboo as a tool of making holes. This system was ineffective and inefficient because the distance and depth of each hole will not be the same. Another problem was that the work with the tugal system resulted in getting tired quickly, because it was done by bending.

Besides of corn planting equipment, another tool that was felt to be needed was a harvesting machine. Farmers usually harvest used human labor with simple tools. After being harvested, the corn was then voted by human labor. Harvest and postharvest which still relied on human labor and on the other hand human labors were decreasing, causing farmers preferred to wholesale or cut down.

\section{Soybean Upsus}

The soybean variety aid that given to program participants was not very popular among farmers. This was due to that soybean varieties produced small grains. While farmers and traders preferred to grow and buy big soybean grains. Therefore, farmers were still working on soybeans by using Anjasmoro variety. The problem with 
processing, harvesting and post-harvesting conditions was almost the same as processing corn by farmers.

\section{CONCLUSION}

Upsus Pajale program in 2018 which was performed in East Java Province, was: (i) realization of LTT in an area of 2,250,605 ha, (ii) 4,170 kg of rice seeds aid and 90 $\mathrm{kg}$ of corn seeds aid; (iii) media dissemination in the form of books as of 1,500 books and in the form of leaflets as of 3,000 sheets, (iv) multiple cropping demonstration plots in an area of 9 ha and agriculture machine tools aid.

In the implementation, there were several benefits felt by farmers including: (i) increased institutional activities in discussing planting time and crop cultivation, (ii) increased cultivation knowledge due to technical guidance activities, (iii) increased seed breeding due to the application of superior varieties from Research and Development institution which began to be liked by farmers, and (iv) increased rice productivity from 6.62 tons to 8.63 tons. On the other hand, problems in the implementation occurred in: (i) recipients of activities where there was a movement in CPCL due to land incompatibility, (ii) seed aid was not sufficient, it was not suitable for the location and seed came after planting time, (iii) agriculture machine tools aid, for tractors was still less, the size of the transplanter and combine were incompatible with the cultivated land and (iv) not all instructions from the Research and Development institution were applied by farmers, due to the problems of availability and habits in adopting cultivation technology.

The adoption of technological innovations in the Upsus Pajale program was very diverse, this can be seen in: (i) the rice seed varieties received and utilized; corn seed varieties were utilized, but the results were not optimal; Soybean seed varieties were not preferred because they produced small grains. (ii) Agriculture machine tool aid preferred in rice plants, especially in cultivating, planting and harvesting activities; the types of given tools were not the same for each group; Agriculture machine tools size did not adjust the condition of farmers' land.

\section{RECOMMENDATION}

Food production enhancement, especially primary foods in the future, will continue to be one of the priorities of national development. Therefore, the Upsus Pajale program can be increased again by: (i) performing all activities in one location starting from the Research and Development institution; procurement or repair of irrigation drains; seed aid according to variety, amount, location and time of planting; in each group of agriculture machine tools aid provided completely from processing, planting and harvesting, the type of agriculture machine tools aid adjusts to the conditions of the recipient's land and there is training for operators who run it, the existence of technical assistance in post-harvest; (ii) the implementation of technical guidance' based cultivation continues to be monitored, and (iii) building institutions especially for water and agricultural machine tools. 


\section{REFERENCES}

Anisa, S. 2018. Efektivitas Program Upsus Pajale Terhadap Peningkatan Pendapatan Usahatani Di Kecamatan Natar Kabupaten Lampung Selatan. [Skripsi]. Lampung: Universitas Lampung

BPS. 2019. Produksi dan Luas Panen Padi Menurut Provinsi

BPTP Jatim. 2019. Laporan Akhir Identifikasi Calon Lokasi, Koordinasi, Bimbingan dan Dukungan Teknologi Upsus Peningkatan Produksi Padi, Jagung Kedelai. Balai Besar Pengkajian dan Pengembangan Teknologi Pertanian.

Busyra, R. G. 2016. Dampak Program Upaya Khusus (Upsus) Padi Jagung Kedelai (Pajale) Pada Komoditas Padi Terhadap Perekonomian Kabupaten Tanjung Jabung Timur. Jurnal Media Agribisnis (MeA) 1 (1): 12-27

Hamayana, U. R. 2017. Pembangunan dan Konflik Sosial di Masyarakat Desa (Studi Etnografi Implementasi Program Upaya Khusus Peningkatan Produksi Padi, Jagung, dan Kedelai di Kabupaten Bondowoso-Jawa Timur). Jurnal Sosial Ekonomi dan Kebijakan Pertanian. Agriekonomika Volume 6, Nomor 2

Irmayanda, D., Azhar, \& Zakiah. 2016. Persepsi Petani Terhadap Peran Tenaga Pendamping Mahasiswa/Alumni Pada Program Upaya Khusus Peningkatan Produksi Padi, Jagung, Kedelai (Upsus Pajale) di Kabupaten Nagan Raya. Jurnal Imiah Mahasiswa Pertanian Unsyiah 1 (1): 481-487

Kementerian Pertanian, 2015. Modul Pendampingan Mahasiswa Dalam Rangka Upaya Khusus Peningkatan Produksi Padi, Jagung dan Kedelai. Kementerian Pertanian. Jakarta.

Kementerian Pertanian, 2015. Pedoman Upaya Khusus (Upsus) Peningkatan Produksi Padi, Jagung, dan Kedelai Melalui Program Perbaikan Jaringan Irigasi dan Sarana Pendukungnya Tahun 2015. Lampiran Permentan RI. No.03/Permentan/ OT.140/2/2015. Tanggal 2 Pebruari 2015.

Nurlaili, A. Warnaen, \& B. Riyan. 2019. Model dan Gaya Komunikasi dalam Program Upaya Khusus Padi Jagung Kedeli. Jurnal Penyuluh. September 2019, Vol 15 No 2

Nugroho, A. D., S. N. H. Utami, Y. Yuslianti, L. Nurrokhmah, M. A. Al Huda, L. Suryani, I. Riyadi, Ulfaizah, T. Septijono \& H. A. N. Adhini. 2017. Pelaksanaan Program Upaya Khusus (Upsus) Swasembada Pangan di Kabupaten Wonosobo Provinsi Jawa Tengah. Jurnal Pengabdian Kepada Masyarakat, 3(1), 1-17. DOI: http: / / doi.org/10.22146/jpkm.27345 ISSN 2460-9447

Sugiyono. 2005. Metode Penelitian Administrasi. Bandung: Alfabeta

Wijaya, I. G. M. A. S., I W. Widyantara dan IDA A. L. D. 2016. Efektivitas Alokasi Input Usahatani Padi Dalam Program Upsus Pajale Di Subak Gadungan Delod Desa, Desa Gadungan, Kabupaten Tabanan. E-Jurnal Agribisnis dan Agrowisata 5 (3) : 527-537.

Wahyudi, D. 2015. Urgensi Pendampingan Terhadap Tingkat Partisipasi Petani Dalam Pelaksanaan Program Swasembada Dan Swasembada Berkelanjutan Di Kota Padangsidimpuan. Agrica Ekstensia 10 (1) : 57-63. 